\title{
ADVANCED APPROACH TO PRODUCTION WORKFLOW COMPOSITION ON ENGINEERING KNOWLEDGE PORTALS
}

\author{
Rina L. Novogrudska, Tatyana N. Kot, Larisa S. Globa \\ National Technical University of Ukraine "Kyiv Polytechnic Institute", Kyiv, Ukraine \\ A.Schill \\ Dresden University of Technology, Dresden, Germany
}

Background. In the environment of engineering knowledge portals great amount of partial workflows is concentrated. Such workflows are composed into general workflow aiming to perform real complex production task. Characteristics of partial workflows and general workflow structure are not studied enough, that affects the impossibility of general production workflow dynamic composition.

Objective. Creating an approach to the general production workflow dynamic composition based on the partial workflows meta-descriptions comparison on engineering knowledge portals.

Methods. Analysis of the partial parameters workflow and characteristics and the structure of general production workflow of knowledge portals made it possible to specify rules for partial workflows inclusion into general production workflow (based on workflows meta-descriptions comparison), to design algebraic model of general production workflow and develop the production workflow tree forming method.

Results. Experimental investigation was made on the application of suggested approach to general production workflow dynamic composition for real complex production workflow of engineering knowledge portal "Calculation of the strength for the power components of magnetic systems".

Conclusions. The approach to the general production workflow dynamic composition on engineering knowledge portals is suggested, that allows, based on comparison of the partial workflows meta-descriptions values, choosing from their set workflows that are required to perform real complex workflow.

Keywords: workflow; production process; knowledge portals; algebraic model.

\section{Introduction}

Research results of independent agencies Gartner Group and Real Story Group [1] for 2011-2012 show that one of the major trends in the development of content management is moving from simple structure sites to large integrated sites of corporate knowledge.

These sites contain a description of the different scientific, engineering or industrial tasks, information about solving methods or providing services to implement them. They also provide users with navigation search and extension of the displayed content with user required detailing.

Integration of data and computing resources by using portal solutions that contain links to geographically distributed resources, allow not only access the information resources, stored in their databases, but also, using data, knowledge and services to implement certain computational tasks. When the number of links to different information and computing resources becomes large enough, the efficient management of information and computing processes becomes almost impossible.

Besides, a number of information and computing resources can dynamically change their location and it is not always possible to manage this process centrally. Thereby the problem of efficient management of information and computing processes on the portal appears. Solving this problem would provide solution for the high-technology and intellectual tasks in various areas, but for the engineering field such solution is extremely relevant.

\section{Knowledge portal introduction}

Knowledge portal is an integrated portal designed to provide meaningful access to structured data and portal knowledge. Information, concentrated in knowledge portals environment makes their usage very common. Thus, technically, knowledge portal should provide integration and collaboration of services, databases and knowledge bases, information storages and computing resources, as well as provide the integration of:

- production processes,

- workflows,

- computing tasks.

In order to provide the correct and holistic interaction of all elements in a single production workflow the mechanism of their integration is required.

Systematization and structuring of information and computing resources on the knowledge portals for their effective interaction are studied by Straccia, Guarino, Cohen, Sowa, Zagorul'ko Yu. and others [2- 
$8]$. For instance, ontological model $[9,10]$ is used as knowledge representation model for knowledge portals in the field of archeology and computer linguistics. Ontology allows describing portal information objects and their information environment, but still some tasks remain unsolved, which are:

- formal description of the portal model as an integrated mathematical system;

- integrating information resources and services to compose a workflow, representing a separate calculation task of the portal [11].

Usually, ontologies are meta-descriptions of the computing and information resources elements. However, the portal workflow design requires selecting from the portal elements set the ones, required for the specific workflow execution. Such task is not trivial and is realized via portal production workflows composition (WFC).

Some considerable number of researches has been recently done on the WFC topic [12]. As well as more specific field has been previously analyzed, which is QoS-aware WFC [13]. Several state-of-the-art studies have shown that most of existing WFC approaches do not cover a sufficient number of QoS subjective parameters. Another important issue is lack of the monitoring phase, meaning that resulting service will fail and won't satisfy the user in case of failure of WF any component.

Thus, the production workflows composition is limited with the following problems:

- impossible to describe metadata of engineering knowledge portal elements clearly structured because these knowledge are created by different groups of scientists, they are unrelated by general formalized rules of knowledge representation, various technologies and tools of knowledge representation are used;

- no unified mechanism for information and computing resources integration;

- inability to describe the characteristics of computing and information resources depending on the particular subject area because of their interdisciplinary nature;

- inability to describe the workflows because some separate works are used to form various engineering calculation tasks.

Solution of the specified problems requires the development of:

- the conceptual model of the engineering knowledge portal;

- a formal apparatus allowing efficient production workflow design;

- the approach to production workflow
Conceptual model of the engineering knowledge portal will allow systematizing and structuring both portal information and computing resources. The formal apparatus, being formal algebraic model of the production workflow, will allow developing a formal context-independent framework for production workflow elements description.

The approach to production workflow composition will allow, using formal algebraic model of the production workflow, to implement a workflow composition into production workflow, providing formal representation and execution of the calculations to solve complex engineering tasks on the portal.

\section{The conceptual model of the engineering knowledge portal}

Engineering knowledge portals are sets of the specific elements, forming users workflow, which are:

- informational resources;

- workflows, which can be production workflows, which are a complete complex engineering task.

The complex structure of the portal is composed by nested and hierarchical calculation tasks. Portals include great amount of production workflows that themselves consists from separate workflows.

Thus, the following conceptual model of the engineering knowledge portal is proposed (1):

$$
\mathrm{CM}(\mathrm{P})=\{\mathrm{PWF}, \mathrm{IR}, \mathrm{WF}\}
$$

Where CM - conceptual model, P - portal, PWF production workflow, IR - information resources, WF - workflow.

To provide knowledge portal functioning, production workflows should be designed and implemented as they are realizing complete complex engineering tasks. Formally, production workflow can be represented as:

$$
\mathrm{PWF}=\{\mathrm{CWF}, \mathrm{IR}, \mathrm{WF}, \mathrm{MD}\}
$$

Where CWF - complex workflow, IR information resources, WF - workflow.

$\mathrm{MD}$ - meta-description.

Each of WF and PWF has a specific set of attributes, describing its features and characteristics. Such set forms the set of meta-descriptions. Metadescriptions allow automating the process of production workflow composition based on the parameters and characteristics of a particular engineering problem domain [14]. Meta-descriptions and their attributes allow identifying each WF in unique way. Meanings of meta-descriptions attributes are stored in database that is filled during preliminary description of WF. Specification of WF metadescriptions is based on Dublin Core standard and defines meta-description as $M=\angle A, D>$, where $A$ is meta-description attribute (represent important 
characteristic or parameter of $\mathrm{WF}$ ) and $D$ is data (represent the name of this parameter or characteristic for appropriate WF). For example, if we describe the set of meta-descriptions of WFs that represent specific engineering portal calculation tasks, they could have such meta-description attributes as title, element material, element_on_calculation, etc. For each calculation task meanings of attributes (that represent data - $D$ ) would be different. Thus, if we consider attribute "element_on_calculation" for WF "Strength calculation" the data for this attribute will be "structure carcass", but for WF "Stability calculation" the data for the same attribute will "support structure".

The following meta descriptions, representing the various characteristics of calculation tasks are specified below (table 1).

Table 1. Workflow meta-description

\begin{tabular}{|l|l|}
\hline \multicolumn{2}{|c|}{ Standard meta-descriptions } \\
\hline $\begin{array}{l}\text { Attribute } \\
\text { name }\end{array}$ & Attribute description \\
\hline Title & $\begin{array}{l}\text { Resource name. This element is } \\
\text { usually a formal name, representing } \\
\text { specific resource. }\end{array}$ \\
\hline Identifier & $\begin{array}{l}\text { A unique identifier. The number of } \\
\text { WF }\end{array}$ \\
\hline Subject & $\begin{array}{l}\text { Narrow subject domain of the } \\
\text { specific WF application }\end{array}$ \\
\hline Description & Textual description of the WF \\
\hline Data & Data type, which WF contains \\
\hline Domain-specific meta-descriptions \\
\hline Parameter & $\begin{array}{l}\text { The parameters, used for } \\
\text { calculations }\end{array}$ \\
\hline Loading & The loads, used in calculations \\
\hline Methods & Calculation methods \\
\hline Element & Calculation element \\
\hline $\begin{array}{l}\text { Measurement } \\
\text { area }\end{array}$ & $\begin{array}{l}\text { Constructs squares, for which } \\
\text { formula calculations are relevant or } \\
\text { which are calculated in formula or } \\
\text { which appear in the calculation }\end{array}$ \\
\hline Connecting meta-descriptions \\
\hline Regulatory & $\begin{array}{l}\text { Title of the normative document } \\
\text { (GOST, ISO, calculation } \\
\text { standards), which is associated with } \\
\text { a WF }\end{array}$ \\
\hline Calculation & $\begin{array}{l}\text { Calculation (functional element), } \\
\text { associated with specific calculation }\end{array}$ \\
\hline Address & $\begin{array}{l}\text { Address, specifying calculation } \\
\text { service allocation }\end{array}$ \\
Materials, required for calculation \\
\hline
\end{tabular}

WF set is stored in an independent repository that has no semantic and logical connections with the PWF repository. Partial WF structure is similar to the PWF structure and includes WF name and parameters. Fig. 1 represents the repository of WF and one PWF, each of them has its own structure and set of parameters.

Search of the WF, to be included into the PWF may be based on comparing WF parameters, as PWF includes only the WF, which have common parameters or parameter ranges of values are overlapped.

Let the set of PWF to be:

where

$$
\mathrm{R}^{\mathrm{t}} \ni \mathrm{r}_{\mathrm{k}}^{\mathrm{t}}, \mathrm{r}_{\mathrm{k}}^{\mathrm{t}}=\left\langle\mathrm{T}_{\mathrm{k}}^{\mathrm{t}}, \mathrm{p}_{\mathrm{k}}^{\mathrm{t}}\right\rangle
$$

$\mathrm{R}^{\mathrm{t}}$-PWF set

$\mathrm{r}_{\mathrm{k}}^{\mathrm{t}}$ - k-th PWF from PWF set

$\mathrm{T}_{\mathrm{k}}^{\mathrm{t}}$ - title of k-th PWF from PWF set

$p_{k}^{t}-$ set of parameters of k-th PWF from PWF set
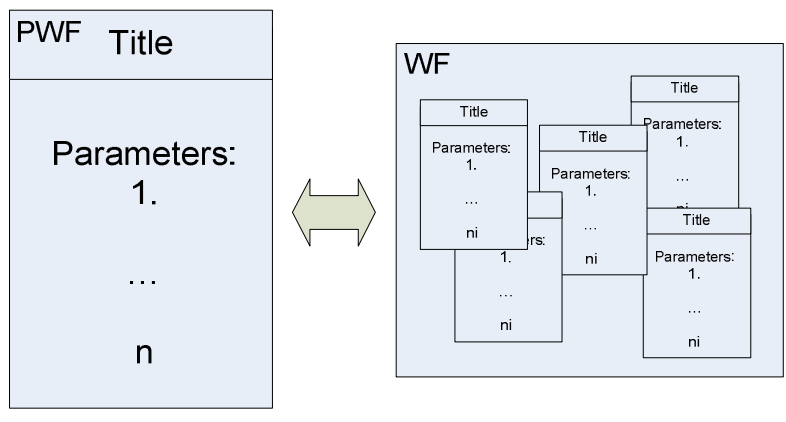

Fig. 1 PWF and WF set

WF set is:

where

$$
\mathrm{R}^{\mathrm{wf}} \ni \mathrm{r}_{\mathrm{l}}^{\mathrm{wf}}, \mathrm{r}_{\mathrm{l}}^{\mathrm{wf}}=\left\langle\mathrm{T}_{\mathrm{l}}^{\mathrm{wf}}, \mathrm{p}_{\mathrm{l}}^{\mathrm{wf}}\right\rangle
$$

$\mathrm{R}^{\mathrm{wf}}-\mathrm{WF}$ set

$\mathrm{r}_{1}^{\mathrm{wf}}-1$-th WF from WF set

$\mathrm{T}_{1}^{\mathrm{Wf}}$ - title of 1-th WF from WF set

$\mathrm{p}_{\mathrm{l}}^{\mathrm{wf}}$ - set of parameter of 1-th WF from WF set

As discussed approach deals with WFs that describe calculation tasks of engineering knowledge portal, assume that each WF is uniquely identified by set of its parameters. It means that two workflows with the same parameters could not have a different semantic in what they do and meanings of WF and PWF parameters could be used for WF integration into the PWF.

Using such formal description, specific methods can be used to automate production workflow composition.

\section{The algebraic model of production workflow}

PWF formal algebraic system allows us to use formal algebraic structures for PWF elements description as well as describe operations with PWF elements when engineering knowledge portal functioning. Formation of PWF and WF involves the description of all their elements, so, on the one hand such description must be oriented on the portal subject 
field, but, on the other hand it should be contextindependent. To develop such kind of description it is suggested to use algebraic structures - objects, data sets and operations of algebra, which allows us to form context-independent description of WF and PWF. Thus the use of algebraic system provides increasing of PWF formation efficiency. Such formal description will allow PWF correct and fast composition.

The algebraic model of PWF is represented by a set of certain type operations on a stored set of information and computing resources $[15,16]$.

The elements of the proposed PWF formal algebraic model are represented below.

Objects. Objects are the basic elements of the algebra on which all operations of algebra are conducted. In PWF algebraic model as the variety of objects set of WF are mentioned.

Data. Elements that are given to the input and output of the system represent the data of algebra. In PWF algebraic model, such objects can be used as data: different constants, variables, results of operations, etc. On the physical level, the data are represented by:

- the values of various parameters and characteristics of the subject domain,

- formulas,

- values boundaries,

- partial services,

- computational procedures that represent calculation tasks [17].

Operations. Set of operations in the PWF algebraic model is divided into two subsets: subset of simple operations and subset of complex operations [18].

Simple operations include:

- elementary algebra operations according to the definition,

- operations on set (given in the set theory),

- logical operations defined by algebra of relations.

Complex operations are:

- the operation of parallel connection $\mathrm{O}^{\mathrm{pc}}$ that describes the process of WF connection with disjunction logical operation;

- the operation of serial connection $\mathrm{O}^{\mathrm{sc}}$ that describes the process of WF connection with disjunction logical operation;

- operation of logical composition $\mathrm{O}^{\mathrm{c}}$ that allows to connect WF by means of known relationship between them and interim WF;

- operation of inversion $\mathrm{O}^{\mathrm{i}}$ that provides a replacement of the WF order to the opposite during the connection of WF in PWF;
- matching operation $\mathrm{O}^{\mathrm{m}}$ that allows to connect WF that are not connected explicitly using some parameters

More detailed description of proposed algebraic system is given in [19].

\section{The approach to the production workflow composition}

Proposed in section 2 and 3 models allow to develop the approach to PWF composition, allowing correctly and dynamically generate a sequence of PWF when portal functioning.

The proposed approach to PWF composition is presented as ordered tree forming method. Whereas the ordered tree is a tree with a root, which defines the order of child nodes, the use of ordered trees to represent PWF will specify the sequence of WF execution.

The suggested approach to PWF tree forming is represented on Fig. 2.

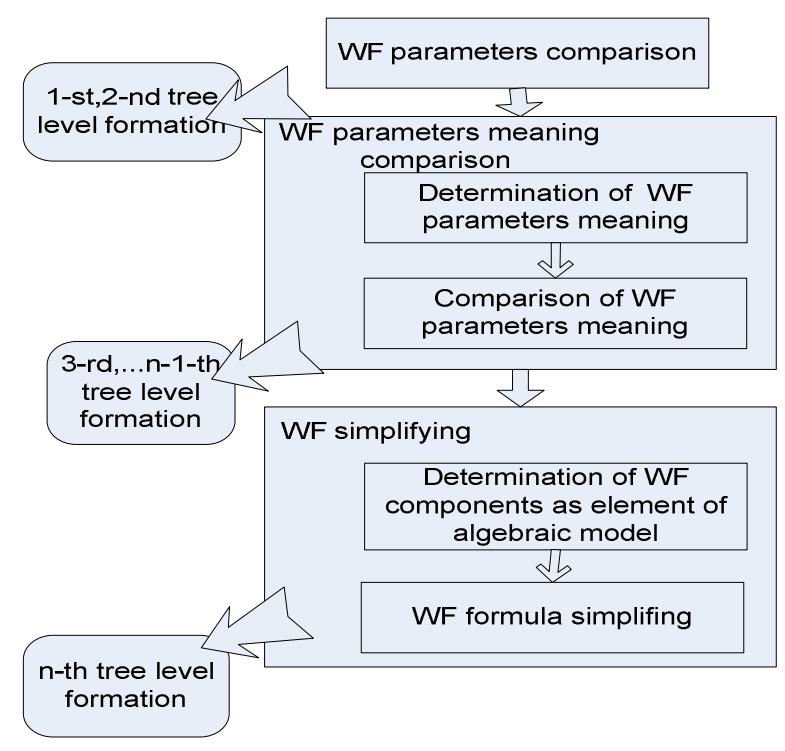

Fig. 2 Tree forming method

The stages of PWF tree forming method are represented below.

Stage 1. At the first stage it is in need to discard from the set $\mathrm{R}^{\mathrm{wf}}$ those $\mathrm{WF}$, for which $\mathrm{p}_{\mathrm{lq}}^{\mathrm{wf}}$ is not equal to $\mathrm{p}_{\mathrm{kj}}^{\mathrm{t}}$

Stage 2. At this stage it is necessary to compare meanings of $\mathrm{p}_{\mathrm{lq}}^{\mathrm{wf}}$ to cut the subset of WF, that has common parameters but their meanings are not equal.

Stage 3. Stage 3 proposes to simplify the WF formula.

Fig. 3 shows tree, that is formed using proposed approach. The root node shows PWF, tree leaves are WF. 


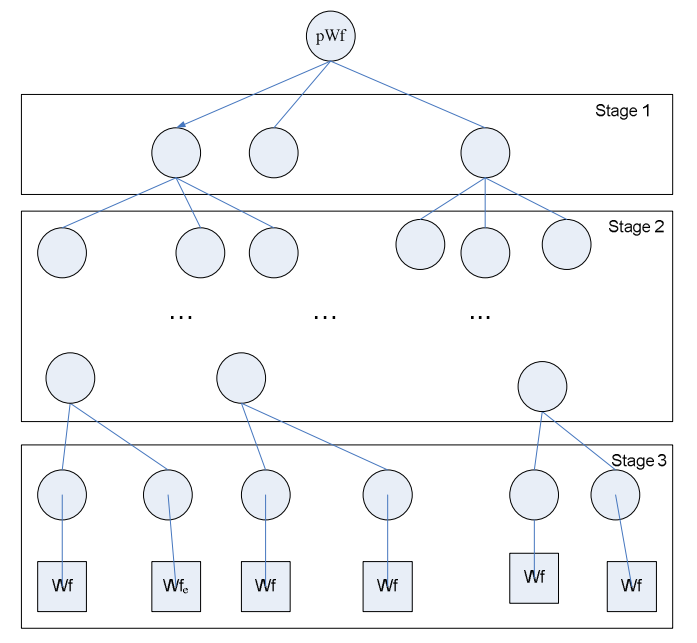

Fig. 3 PWF tree

More detailed description of the suggested approach stages is represented below.

Stage 1. Comparing WF parameters

At the first stage it is necessary to include WF into the PWF comparing and selecting the WF, which parameters match the PWF parameters. It is necessary to analyze the WF set and choose from it those WF, which parameters match the PWF parameters according to the rule:

$$
P_{d}^{t}=\bigcup_{i}^{m} P_{i}^{w f}
$$

whereby possible the fulfilment:

$$
\text { where } i, j=\frac{P_{i}^{w f}}{1, m} \cap P_{j}^{w f}
$$

The result is a subset of WF set satisfying the rule (5) and PWF tree with second level tops, which are elements of this subset.

Stage 2. Checking WF parameters values

Partial WF are selected to concatenate into PWF based on comparing subsets of parameters sets corresponding to these WF. The comparisons are done based on the occurrences or equality of these parameters meaning range of values.

Thus, on the stage of WF parameter values verification WF parameters values from WF set, formed on the first stage, are compared to PWF corresponding parameters:

$$
M\left(p_{i k}^{t}\right)<M\left(p_{j t}^{w f}\right)
$$

under the condition that $p_{i k}^{t}=p_{j t}^{w f}$

The result can be one of the following options:

1. Domains match

$$
M\left(p_{i k}^{t}\right)=M\left(p_{j t}^{w f}\right)
$$

in this case domain of the $k$-th parameter of $i$-th PWF matches domain of $t$-th parameter of $j$-th WF, ie specified WF is included as a node into PWF tree.

2. One domain includes another one:
2.1 .

$$
\mathrm{M}\left(\mathrm{p}_{\mathrm{jt}}^{\mathrm{wf}}\right) \subset \mathrm{M}\left(\mathrm{p}_{\mathrm{ik}}^{\mathrm{t}}\right)
$$

in this case domain of the $t$-th parameter of $j$-th WF includes domain of $k$-th parameter of $i$-th PWF, ie specified WF is included as a node into PWF tree,

2.2.

$$
M\left(p_{i k}^{t}\right) \subset M\left(p_{j t}^{w f}\right)
$$

in this case domain of the $\mathrm{k}$-th parameter of $\mathrm{i}$-th PWF includes $t$-th parameter of $j$-th WF, ie specified WF is included as a node into PWF tree. But analysis of the parameter values for other WF continues in order to find WF, which parameter values domain in combination with this WF parameter values domain will form PWF parameter values domain.

3. Domains overlap

$$
M\left(p_{i k}^{t}\right) \cap M\left(p_{j t}^{w f}\right)
$$

in this case domain of the $k$-th parameter of i-th PWF overlap domain of $t$-th parameter of $j$-th WF, ie specified WF is included as a node into PWF tree. But analysis of the parameter values for other WF continues in order to find WF, which parameter values domain in combination with this WF parameter values domain will form PWF parameter values domain:

$$
M\left(p_{j t}^{w f}\right) \cup M\left(p_{h d}^{w f}\right)=M\left(p_{i k}^{t}\right)
$$

4. Domains don't overlap

$$
M\left(p_{i k}^{t}\right) \neq M\left(p_{j t}^{w f}\right)
$$

in this case domain of the k-th parameter of i-th PWF don't overlap domain of t-th parameter of $j$-th WF, ie specified WF is not included into PWF tree.

Stage 3. Simplifying WF formula

The third stage operates with specific rules and operations to represent the formula of WF (described using proposed algebraic model) in minimized form. Such simplifications rules are based on properties of operations [20]. Operations properties form the basis for the main identities of algebraic model underlying the formulas transformation for the purpose of simplification or reduction to a certain form.

The resulting PWF tree can be saved in the knowledge base as a pattern for further use with the possibility of its modification. It can be modified using standard operations on trees.

Presenting the engineering tasks in the form of PWF with tree structure allows processing each node of the tree, which represents a different WF, simultaneously, avoiding tree branches, which are independent of each other, which will minimize time for PWF composition.

\section{Example of the production workflow composition}

The example of proposed approach to PWF composition is considered below. PWF represents real 
complex engineering calculation task that consists of WFs that represents more simple engineering calculation tasks. Assume that there is PWF that represent engineering calculation task «Calculation of the strength for the power components of magnetic systems» with description structure:

$$
\mathrm{r}_{1}^{\mathrm{t}}=\left\langle\mathrm{T}_{1}^{\mathrm{t}}, \mathrm{p}_{1 \mathrm{j}}^{\mathrm{t}}\right\rangle, \mathrm{j}=1, \mathrm{n}
$$

where

$\mathrm{T}_{1}^{\mathrm{t}}-$ «Calculation of the strength for the power components of magnetic systems»»

$\mathrm{p}_{11}^{\mathrm{t}}-\mathrm{a} 1=10-$ allowable pressure

$p_{12}^{\mathrm{t}}-\mathrm{E}_{2}=52$ - average loading

$\mathrm{p}_{13}^{\mathrm{t}}-\mathrm{E}_{1}=48$ - basic loading

$\mathrm{p}_{14}^{\mathrm{t}}-\mathrm{R}=5$ - winding radius

$\mathrm{p}_{15}^{\mathrm{t}}-\mathrm{c}=10-$ the length of connection between

construction body and winding

$\mathrm{p}_{16}^{\mathrm{t}}-1=15$-critical length

$\mathrm{p}_{17}^{\mathrm{t}}-\mathrm{D}_{\mathrm{m}}=<10 \ldots 12>=$ maximal diameter

$\mathrm{p}_{18}^{\mathrm{t}}-\mathrm{Pi}=18-$ dimension of construction body

$\mathrm{p}_{19}^{\mathrm{t}}-\eta=20-$ critical pressure

$\mathrm{p}_{110}^{\mathrm{t}}-\phi=5-$ allowable tension pressure

$\mathrm{p}_{111^{\mathrm{t}}}^{\mathrm{t}} \mathrm{v}=28-$ winding length

$\mathrm{p}_{112}^{\mathrm{t}}-\mathrm{d}=44-$ winding strength

$\mathrm{p}_{113}^{\mathrm{t}}-\mathrm{e}=6-$ constant of static level

$\mathrm{p}_{114^{-}}^{\mathrm{t}} \mathrm{M}=12-$ general membrane strength

At the 1-st stage the analysis of WF set is done. It is in need to choose from this set only those WF that satisfy condition (5). Such WF are:

1. Calculation of basic parameters: $r_{1}^{\text {wf }}=$ $\left\langle T_{1}^{\mathrm{wf}}, \mathrm{p}_{1 \mathrm{j}}^{\mathrm{wf}}\right\rangle, \mathrm{j}=1, \mathrm{n}$, where: $\mathrm{T}_{1}^{\mathrm{wf}}$ is $«$ Calculation of basic parameters», $p_{11}^{w f}-d=44, p_{12}^{w f}-e=6, p_{13}^{w f}-M=12$

2. Verifying calculation: $r_{2}^{w f}=\left\langle T_{2}^{w f}, p_{2 j}^{w f}\right\rangle, j=1, n$, where: $\mathrm{T}_{2}^{\mathrm{wf}}$ is «Verifying calculation», $\mathrm{p}_{21}^{\mathrm{wf}}-\mathrm{a} 1=10$, $\mathrm{p}_{22}^{\mathrm{wf}}-\mathrm{E}_{2}=52, \mathrm{p}_{23}^{\mathrm{wf}}-\mathrm{E}_{1}=48, \mathrm{p}_{24}^{\mathrm{wf}}-\mathrm{R}=5, \mathrm{p}_{25}^{\mathrm{wf}}-\mathrm{c}=10$, $\mathrm{p}_{26}^{\mathrm{wf}}-\mathrm{l}=15, \mathrm{p}_{27}^{\mathrm{wf}}-\mathrm{D}_{\mathrm{m}}=<10, \ldots, 12>, \mathrm{p}_{28}^{\mathrm{wf}}-\mathrm{Pi}=18, \mathrm{p}_{29}^{\mathrm{wf}}-$ $\eta=20, p_{210}^{w f}-\phi=5, p_{211}^{w f}-v=28$.

Some more WF are characterized by parameters similar to parameters of $r_{1}^{\mathrm{wf}}$. They are: static strength calculation, critical constant calculation, resistance calculation:

1. Static strength calculation: $r_{3}^{w f}=\left\langle T_{3}^{\mathrm{wf}}, p_{3}^{\mathrm{wf}}\right\rangle$, where $T_{3}^{\mathrm{wf}}$ - "Static strength calculation", $p_{31}^{\mathrm{wf}}-\mathrm{a} 1=10, p_{32}^{\mathrm{wf}}-E_{2}=52, p_{33}^{\mathrm{wf}}-E_{1}=48$, $p_{34}^{\mathrm{wf}}-\mathrm{R}=5, \quad p_{35}^{\mathrm{wf}}-\mathrm{c}=10, p_{36}^{\mathrm{wf}}-1=15, p_{37}^{\mathrm{wf}}-$ $D_{m}=<10 \ldots 12>$.

2. Critical constant calculation: $\mathrm{r}_{4}^{\mathrm{wf}}=\left\langle\mathrm{T}_{4}^{\mathrm{wf}}, \mathrm{p}_{4}^{\mathrm{wf}}\right\rangle$, where: $T_{4}^{\mathrm{y}}-$ "Critical constant calculation", $p_{41}^{\mathrm{wf}}-$ $\mathrm{a} 1=10, p_{42}^{\mathrm{wf}}-E_{2}=52, p_{43}^{\mathrm{wf}}-E_{1}=48, p_{44}^{\mathrm{wf}}-\mathrm{R}=5, p_{45}^{\mathrm{wf}}-$ $\mathrm{c}=10, p_{46}^{\mathrm{wf}}-\mathrm{l}=15, \mathrm{p}_{47}^{\mathrm{wf}}-\mathrm{D}_{\mathrm{m}}=<15 \ldots 52>$
3. Resistance calculation: $r_{5}^{\mathrm{wf}}=\left\langle\mathrm{T}_{5}^{\mathrm{wf}}, \mathrm{p}_{5}^{\mathrm{wf}}\right\rangle$, where: $T_{5}^{\mathrm{wf}}-$ "Resistance calculation", $p_{51}^{\mathrm{wf}}-\mathrm{Pi}=18, p_{52}^{\mathrm{wf}}-$ $\eta=20, p_{53}^{\mathrm{wf}}-\phi=5, \mathrm{p}_{54}^{\mathrm{wf}}-\mathrm{v}=28$

As the result, we receive the subset of WF that satisfies condition (5). Formed PWF tree is shown on Fig. 4. The root node show PWF: $r_{1}^{t}-$ "Calculation of the strength for the power components of magnetic systems", intermediate nodes are WF: $\mathrm{r}_{1}^{\mathrm{wf}}$ "Calculation of basic parameters" and $\mathrm{r}_{1}^{\mathrm{wf}}$ "Verifying calculation", leaves are WF: $r_{3}^{w f}$ - "Static strength calculation", $\mathrm{r}_{4}^{\mathrm{wf}}$ - "Critical constant calculation", $\mathrm{r}_{5}^{\mathrm{wf}}$ - "Resistance calculation".

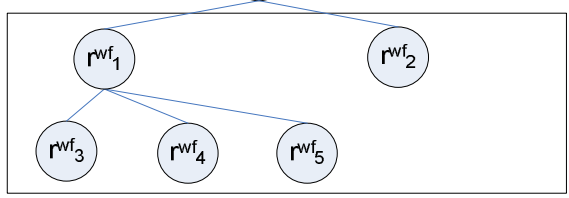

Fig. 4 PWF tree on the stage 1

At 2-nd stage, the comparison of WF parameters is held according to the rule (7):

Let us consider parameter $D_{m}$ of described calculations:

- for calculation of the strength for the power components of magnetic systems: $\mathrm{D}_{\mathrm{m}}=\langle 10, \ldots, 12\rangle$,

- for Verifying calculation:

$\mathrm{D}_{\mathrm{m}}=<10, \ldots, 12>$,

- for Static strength calculation:

$\mathrm{D}_{\mathrm{m}}=<0, \ldots, 12>$,

- for Critical constant calculation:

$\mathrm{D}_{\mathrm{m}}=<15, \ldots, 52>$.

Let us compare the meanings of these parameters:

$\mathrm{M}\left(p_{17}^{t}\right) \diamond \mathrm{M}\left(p_{27}^{w f}\right) \diamond \mathrm{M}\left(p_{37}^{w f}\right) \diamond \mathrm{M}\left(p_{47}^{w f}\right)$

The range of value for $p_{17}^{t}$ of "Calculation of the strength for the power components of magnetic systems" is equal to the range of value for $p_{27}^{\mathrm{wf}}$ of "Verifying calculation". The range of value for $p_{27}^{w f}$ of "Verifying calculation" is equal to $\mathrm{p}_{37}^{\mathrm{wf}}$ of "Static strength calculation" and is not equal to $p_{47}^{w f}$ of "Critical constant calculation":

$M\left(p_{17}^{t}\right)=M\left(p_{27}^{w f}\right), M\left(p_{27}^{w f}\right)=M\left(p_{37}^{w f}\right) \neq M\left(p_{47}^{w f}\right)$

It means that we can reduce the set of WF, excluding critical constant calculation from this set. PWF tree after 2-nd stage is shown on Fig. 5. Tree includes the same nodes and leaves as tree represented on Fig. 4, but $r_{4}^{\mathrm{wf}}$ - "Critical constant calculation" - is to be removed from the tree as the result of the 2-nd stage. 


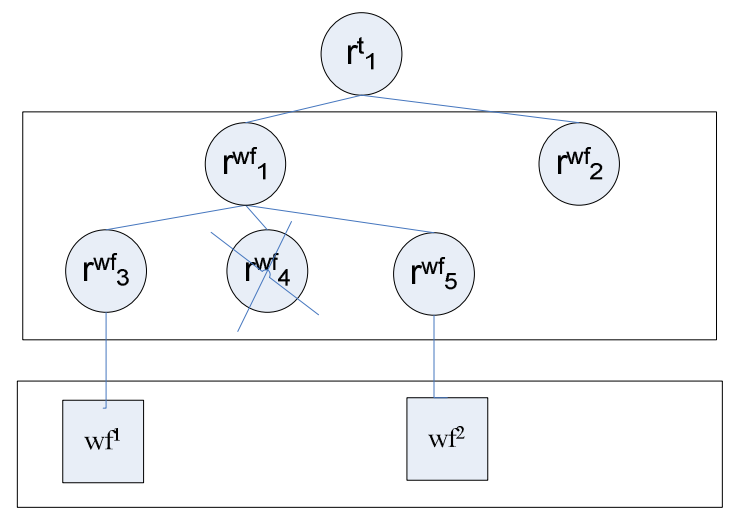

Fig. 5 PWF tree

Such example of proposed approach implementation to PWF, representing real engineering calculation task, provides the proof of correct representation and execution of complex engineering calculation tasks on the knowledge portal.

\section{Conclusions}

The paper presents an approach to PWF composition on engineering knowledge portals. A conceptual model of a knowledge portal is proposed, allowing systematization and structuring of the information and computing resources of the portal; as well as a formal algebraic system for PWF composition, allowing us to set the contextindependent formal structures for PWF elements description.

The proposed approach to PWF composition is presented as ordered tree forming method. It allows structuring the WF and improves the efficiency of their performance through parallel processing of independent tree branches of PWF. It also allows integrating partial calculation tasks into general calculation of engineering portal, performed on user request demand.

Future work is aimed on implementation of suggested approach to different types of complex engineering calculation tasks. This will allow us to approve its applicability and efficiency on real world scenarios.

Future work supposes the development of software tool for production workflow composition, their future monitoring and reconfiguration. As a basis already developed workflow design and analysis tool can be used [21] with further extension of its functionality. Developed software tool will be tested and verified on real world scenarios when developing engineering knowledge portals.

Quantitative evaluation of the proposed approach and tool efficiency will be obtained: the average time of PWF composition, PWF correctness and quality will be validated.

\section{References}

1. Tony Byrne, Real Story Group Blog - Digital workplace and enterprise architecture: two sides to same coin, (2012) - http://www.realstorygroup.com/Blog/2311Digital-workplace-and-enterprise-architecture-two-sides-tosame-coin

2. John F. Sowa The role of logic and ontology in language and reasoning, Chapter 11 of Theory and Applications of Ontology: Philosophical Perspectives, edited by R. Poli \& J. Seibt, Berlin: Springer, 2010, pp. 231263.

3. F. Bobillo, U. Straccia. Aggregation Operators for Fuzzy Ontologies. Applied Soft Computing 13(9):38163830, 2013

4. Guarino N., Guizzardi G. In Defense of Ontological Foundations for Conceptual Modeling. In: Scandinavian Journal of Information Systems, vol. 18(1) pp. 115 - 126. 2006.

5. D. Movshovitz-Attias and W.W. Cohen. 2012. Boot-strapping biomedical ontologies for scientific text using nell. Technical report, Carnegie Mellon University, CMU-ML-12-101.

6. Zagorulko U.A. and others. An approach to portals of scientific knowledge development // Avtometriya. 2008. V. 44. № 1. P. 100-110.

7. Gavrilova T.A. Horoshevskyi V.F. Knowledge bases of intellectual systems. - S-P.: Piter, 2000

8. Kolb D.G. Web-oriented realization of semantic models for intellectual systems // Proceedings of scientific conference "«Open Semantic Technologies for Intelligent Systems (OSTIS-2012)", - Minsk, 2012. - P. 111-122.

9. Globa L. Method of heterogeneous information resources structuring and systematizing for Internet portals development / Globa L., Novogrudska R., Oriekhov O. // In: IEEE EUROCON, pp. 319-326 (2013).

10. Zagorulko U.A. and others. The technology of scientific portals development: experience of application, problems and prospects. Proceedings of international scientific conference «SWC-technique and telecommunication technologies» (Crymico' 2011). Sevastopol: Veber, 2011. - P. 51-54.

11. Globa L.S., Novogrudska R.L., Models and methods of information and computation resources integration Proceedings of scientific conference "«Open Semantic Technologies for Intelligent Systems (OSTIS2012)", - Minsk, 2012. - P. 142-148

12. Pukhkaiev, D., Kot, T., Globa, L., Schill, A.: A novel SLA-aware approach for web service composition. In: IEEE EUROCON, pp. 327--334 (2013)

13. Pukhkaiev, D., Kot, T., Globa, L., Schill, A.: Yet another SLA-aware WSC System. Lecture Notes in Business Information Processing, Volume 176, 2014, pp 197-205

14. Globa L.S., Novogrudska R.L., The development of engineering calculations for knowledge portals // Proceedings of scientific conference «Open Semantic Technologies for Intelligent Systems (OSTIS - 2014)». Minsk, 2012. - P. 137-143

15. Telenyk S.F. Logic of computational processes representation in intellectual system SmartBase // System 
technologies. System modeling of technological processes 1999. - Series. 6. - C.131 -139.

16. Pavlov A.A., Telenyk S.F. Informational technologies and algorithmization in management. K.:Tehnika, 2002. - 344 p.

17. Shahovska N.B. Data space in sphere of scientific research // Modeling and information technologies. - 2008. - № 45. - P. 132-140

18. John Dwyer. An Introduction to Discrete Mathematics for Business \& Computing. ISBN 978-1907934-00-1. (2010)

19. Globa L.S., Novogrudska R.L., An approach to formal system for knowledge portals development,
Ontology of designing. - 2014. - №2(11). - ISSN 22239537- P.40-59

20. Kenneth H. Rosen. Discrete Mathematics: And Its Applications. McGraw-Hill College. ISBN 978-0-07288008-3. (2007)

21. Kot T., Reverchuk A., Globa L., Schill A. A novel approach to increase efficiency of OSS/BSS workflow planning and design. - Springer: Lecture Notes in Business Information Processing. - 2012. - Vol. 117. - P. 142-152.

Received in final form on April 9, 2015

\section{Р. Новогрудська, Т. Кот, Л. Глоба, О. Шиль.}

Прогресивний підхід до формування виробничого робочого процесу на інженерних порталах знань

Проблематика. В середовищі інженерних порталів знань зосереджена велика кількість часткових робочих процесів, що поєднуються у загальний робочий процес, з метою виконання реальної комплексної виробничої розрахункової задачі. Характеристики таких часткових робочих процесів та структура загальних робочих процесів $\epsilon$ недостатньо дослідженими, що впливає на неможливість динамічного формування загального виробничого робочого процесу.

Мета досліджень. Створення підходу до динамічного формування загального виробничого робочого процесу на основі порівняння метаописів часткових робочих процесів інженерних порталів знань.

Методика реалізації. Аналіз параметрів та характеристик часткових робочих процесів, а також структури загальних виробничих робочих процесів порталів знань дав змогу задати правила включення часткових робочих процесів у загальні виробничі робочі процеси (на базі порівняння значень метаописів робочих процесів), побудувати алгебраїчну модель загального виробничого робочого процесу, а також розробити метод формування дерева виробничого робочого процесу.

Результати досліджень. Виконано експериментальне дослідження по застосуванню запропонованого підходу до динамічного формування загального виробничого робочого процесу для реального комплексного виробничого робочого процесу інженерного порталу знань «Розрахунок на міцність силових магнітних систем».

Висновки. Запропоновано підхід до динамічного формування загального виробничого робочого процесу на порталах інженерних знань, що дозволяє на основі порівняння значень метаописів часткових робочих процесів обрати 3 їх множини тільки ті, що необхідні для виконання реального комплексного робочого процесу.

Ключові слова: робочий процес; виробничий процес; портал знань; алгебраїчна модель.

Р. Новогрудская, Т. Кот, Л. Глоба, А. Шиль.

Прогрессивный подход к формированию производственного рабочего процесса на инженерных порталах знаний

Проблематика. В среде инженерных порталов знаний сосредоточено большое количество частичных рабочих процессов, которые объединяются в общий рабочий процесс с целью выполнения реальной комплексной производственной расчетной задачи. Характеристики таких частичных рабочих процессов и структура общих процессов недостаточно исследованы, что влияет на невозможность динамического формирования общего производственного процесса.

Цель исследований. Создание подхода к динамическому формированию общего производственного рабочего процесса на основании сравнения метаописаний частичных рабочих процессов инженерных порталов знаний.

Методика реализации. Анализ параметров и характеристик частичных рабочих процессов, а также структуры общих производственных рабочих процессов порталов знаний дал возможность задать правила включения частичных рабочих процессов в общие производственные рабочие процессы (на базе сравнения значений метаописаний рабочих процессов), построить алгебраическую модель общего производственного процесса, а также разработать метод формирования дерева производственного рабочего процесса.

Результаты исследований. Выполнено экспериментальное исследование по применению предложенного подхода к динамическому формированию общего производственного рабочего процесса для реального комплексного производственного рабочего процесса инженерного портала знаний «Расчет на прочность силовых магнитных систем».

Выводы. Предложено подход к динамическому формированию общего производственного рабочего процесса на порталах инженерных знаний, который позволяет на основании сравнения значений метаописаний частичных рабочих процессов выбрать из их множества те, которые необходимы для выполнения реального комплексного рабочего процесса.

Ключевые слова: рабочий процесс; производственный процесс; портал знаний; алгебраическая модель. 